Egyptian Journal of Botany

\title{
Mohamed Abdel Fattah Al-Kassas: The Founding Father of Egypt's Ecology
}

\author{
Hamed Ead ${ }^{(1)}$, Tarek Y.S. Kapiel ${ }^{(2) \#}$ \\ ${ }^{(1)}$ Chemistry Department, Faculty of Science, Cairo University, Giza, Egypt; ${ }^{(2)}$ Botany \\ and Microbiology Department, Faculty of Science, Cairo University, Giza, Egypt.
}

\begin{abstract}
66 ROF. KASSAS is the very embodiment of all that is good in a human being. His life is his message. He has stood for achieving harmony between humankind and nature as well as peace and harmony among nations." M. S. Swaminathan*

Professor Mohamed Abdel Fattah Al-Kassas (July 6, 1921 - March 21, 2012) was one of the most extraordinary scientific luminaries in Egypt, he is among the pioneers who have warned the world against the hazards of desertification and has played an important role in designing and implementing a number of UNESCO programs such as Man and the Biosphere.

He was professor emeritus for the Botany University of Cairo, Egyptian botanist and conservationist, a specialist in the ecology of desert plants, his environmental and botanical work over many decades cut a broad and fertile swath in areas of desert ecology and environmental changes over time, especially in relation to desertification - a process he is held to have brought to both public and scientific attention and was among the first to publish on the topic of desertification. He studied at the University of Cairo, where he received a B.Sc. in 1944 and an M.Sc. in 1947, and at the University of Cambridge (Ph.D. in 1950). He was a member of the Egyptian Academy of Science and the Institute of Egypt. Prof. Kassas was an advisory member of the United Nations Environment Programme from its beginning, He was also the notable President (1978-1984) of the International Union for Conservation of Nature (IUCN), a fellow of the Indian National Academy of Science, the World Academy of Art and Science, and an honorary member of the Club of Rome.
\end{abstract}

Keywords: Egyptian desert, Ecology of the Red Sea, Mohamed Abdel Fattah Al-Kassas, The environment in Egypt.

\section{Introduction}

The Late Mohamed Abdel Fattah Al-Kansas (commonly known as Kassas) was born on July 6, 1921 and grew up in a tiny fishing northern village located at the junction of the Mediterranean and Lake Burullus. He dedicated his life to research and scientific endeavors to protect and conserve Nature for the future of humanity and displayed an early interest in natural history. His childhood was spent exploring the countryside and studying the local flora and fauna. Summer holiday experiences on the West coast of Nile piqued his interest in natural history, where he would eventually return to conduct research on fish farming.

He developed an early passion for nature and biodiversity. In 1940, he moved to Cairo to study science at Fouad I University, graduated in 1944 with distinct honors, where he was appointed

${ }^{*} \mathrm{He}$ is an Indian geneticist and administrator, known for his role in India's Green Revolution. Swaminathan has been called the "Father of Green Revolution in India" for his role in introducing and further developing high-yielding varieties of wheat in India. He is the founder of the MS Swaminathan Research Foundation

\footnotetext{
\#Corresponding author email: tkapiel@sci.cu.edu.eg Tarek Y.S. Kapiel iD 0000-0002-2213-8911

Received 12/08/2021; Accepted 27/10/2021

DOI: $10.21608 /$ ejbo.2021.90393.1760

Edited by: Prof. Dr. Salama A. Ouf, Faculty of Science, Cairo University, Giza 12613, Egypt.

(C)2021 National Information and Documentation Center (NIDOC)
} 
Demonstrator in the Botany Department; his acute interest in and knowledge of nature led him to major in botany. He was obtained awarded a Master's degree in 1947 from the then Fouad I University (now Cairo University), and the Ph.D. degree in 1950 from Cambridge University, England. After his return to Egypt, he was assigned positions in the teaching staff of the Botany Department in the Faculty of Science at Fouad I University, where he was then promoted to Professor of the Applied Botany Chair in 1965 and became a full-time Professor since 1981. He was delegated Assistant Director-General for Sciences at the Arab Organization for Education and Culture (1972-1976).

The fact that Cairo is located in the desert led him to focus his research on plant ecology in arid lands. His interest in desertification emerged a few years later, that is, between 1953 and 1956, when he taught botany at the University of Khartoum in Sudan. In his 60 years of research, his principal interests lie in plant ecology, especially in arid lands. He and his students surveyed plant life in the deserts and coastal lands of Egypt, Sudan, Saudi Arabia, and Iraq and contributed to the basic understanding of the ecology of the desert vegetation. He was among the pioneers who warned the world against the hazards of desertification. Furthermore, he contributed to the UNESCO Arid Lands Research Program, including the ecological maps of the Mediterranean Basin (1950-1960), and to the scientific preparation for the United Nations Conference on Desertification (1977). He was a member of the panel of Senior Advisors to the United Nations Environment Program (UNEP) between 1973 and 1992.

He was at the forefront of introducing terminologies, such as biodiversity, desertification, protectorates, conservation development, and environmental education. This commitment earned- Prof. Kassas the title "Father of the Egyptian Environment" and gained him international recognition as one of the greatest ecologists of our times.

In 1969, Kassas presented his paper on desertification at an international conference on arid lands in Virginia, U.S.A. "This was the first time that the word 'desertification' was used in English, he says, and it became a bad omen, because the 70's witnessed unprecedented droughts in Africa that accelerated the process of desertification in the Sahara." Between 1978 and 1984, Mohamed Kassas became the President of the International Union for Conservation of Nature (IUCN), the world's oldest and largest environmental network, which gathers 1,000 governmental and non-governmental organizations along with 11,000 volunteers from 160 countries worldwide.

Prof. Kassas participated in the formulation, development, and outline of programs and policies for Men and the Biosphere under UNESCO, the SCOPE mid-term program, UNEP priority areas, and IUCN, including the World Conservation Strategies in 1980 and the World Charter for Nature in 1982. In addition, he participated in the preparation of the Plan of Action for the UN Water Conference and the Preparatory Process for the UN Conference on Desertification. Both conferences were held in 1977, whereas the UNEP assessment of worldwide desertification was conducted in 1984 and 1991.

The majority of Kassas' professional achievements are rooted in his deep interest in nature and his belief in the benefits of education, particularly its ability to initiate change in human cognition and action. He is recognized as one of the founders of environmental education at the national and international levels. Throughout his life, he advised, supported, and encouraged countless national and international organizations and individuals in their effort to establish environmental education policies and program throughout his home country of Egypt and across the world.

His interests introduced him into the international scene. He was one of the writers of the first internationally accepted definition of environmental education, which was approved at an environmental education conference of the World Conservation Union.

Contributions to movements of protecting the environment in Egypt

His role at the national level was undoubtedly remarkable. He was appointed a member of the Shura Council in 1981 and spurred interest regarding environmental issues in Egypt. He helped several NGOs raise funds and actively lobbied to develop institutions that concentrate on environmental issues at universities. In addition, 
he created a library for environmental science at Cairo University, with which experts throughout the country consult. In 1997, Kassas announced his opposition to the New Valley Project (or Toshka Project), which consisted of building a system of canals to transport water for irrigation from Lake Nasser to the Western Desert and increase the amount of agricultural land.

Prof. Kassas initiated and led campaigns to protect and conserve the environment, which resulted in the establishment of the National Programme for Studies on Coastal Erosion in 1970 (supported by UNDP-UNESCO) and the National Post-High Dam Research Programme for integrated studies under the auspices of the Academy of Scientific Research and Technology. Subsequently, the National Water Research Center (an institute for post-high dam research) and interdisciplinary research programs on: (a) The desert biome (Alexandria University and the University of Utah; 1972), and (b) The Wadi Allaqi Research Project (Faculty of Science, Aswan; 1984) were established. He proposed the National Reserves of Nature Act and a decree for constructing the first national park in Egypt at Ras Mohamed in 1983. Furthermore, he drafted subsequent decrees for other protected areas in Egypt and established several environmental nongovernmental organizations (NGOs). In 1992, he spearheaded the National Biodiversity Unit under the Egyptian Environmental Affairs Agency.

\section{In the Arab world}

During his work with the Arab League's Educational, Cultural and Scientific Organization between 1973 and 1976, Prof. Kassas initiated and planned several programs on environmental studies, such as the Strategic Action Programme for the Red Sea and Gulf of Aden in 1973, which embraced eight countries, and Architecture and Environment in Arab Countries and Environmental Education in Arab Countries. Both programs were initiated in 1974 and comprised 20 countries. Lastly, he helped establish the North African Green Belt Programme in 1976 for five countries.

\section{Overview of his research interests}

Prof. Kassas has published extensively and was a member of the editorial boards of several international journals in the fields of ecology and environmental sciences. Scholars interested in Egypt's environmental issues are familiar with his work and his lengthy and rich career, which reflects the environmental history of Egypt in the Arab world and worldwide.

Habitat and plant communities in the Egyptian desert

During a long period that extends from 1952 to 1970 , Kassas described habitat and plant communities in the Egyptian desert and the features of desert communities. His papers covered the I. Introduction, II. The Features of a Desert Community, III. The Wadi Bed Ecosystem, VI. The Units of a Desert Ecosystem, V. The Limestone Plateau, and VII. Geographical Facies of Plant Communities (Kassas, 1952, 1953; Kassas \& Imam, 1954; Kassas, 1956; Kassas \& Girgis, 1964; Kassas \& Zahran, 1965; Kassas, 1970, respectively).

The first paper of this series (Kassas, 1952) provides a classification of the types of desert habitats into a number of ecosystems related to the main land-form systems. The subsequent papers present the general features of the desert community (Kassas, 1953), the wadi bed ecosystem (Kassas \& Imam, 1954), and the gravel desert ecosystem (Kassas \& Imam, 1959).

Furthermore, Kassas \& Imam (1954) described the general features of the wadi bed vegetation and concluded that communities dominated by Tamarix spp. or Acacia tortilis are among the climax communities.

In addition, Kassas (1955) described the relationships between climate, soil, vegetation, and other components of desert ecosystems, such as those of the coastal lands of the Mediterranean and the Red Sea. In the Erkwit plateau, Kassas (1956) distinguished five main communities dominated and co-dominated by (1) Maytenus senegalensis, (2) M. senegalensis and Euphorbia abyssinica, (3) E. abyssinica, (4) Dracaena ombet and E. abyssinica, and (5) Euphorbia thi. These communities occur in a distinct zonation pattern, which is described in the subsequent text.

Kassas (1957) stated that during his first visit to Khor Arbaat in December 1953, he was inspired by the image of the luxuriant growth of Tamarix mannifera and A. tortilis. In the Sudan, the vegetation of the coastal plain of the Red Sea is formed by a widely open community, where the average cover is less than $5 \%$, as well as scrubland types, where the coverage may reach $60 \%$. Sterile 
areas are among the obvious features of the plain.

Kassas \& Girgis (1964) described one type of the rocky plateau ecosystem, namely, the limestone plateau. The surveyed area is approximately $2,000 \mathrm{~km}$. The climate of the area is Saharan Mediterranean.

The region of North Africa extends along the southern Mediterranean. According to the World Atlas of Desertification (UNEP, 1992), Africa north of the Sahara includes Morocco, Algeria, Tunisia, Libya, and Egypt as well as Western Sahara and Cape Verde. This area encompasses 545.3 million ha, $98.3 \%$ of which are drylands vulnerable to desertification and the hazards of drought. Alternatively, hyper-arid territories represent $70.6 \%$ of the total area (Kassas, 1996).

\section{Ecology of the Red Sea}

Kassas \& Zahran (1965) examined the ecology of the Red Sea littoral salt marsh in Egypt and coastal land ranging from El-Galala El-Qibliya to Hurghada. Disturbances due to human activities are known to influence desert vegetation. Thus, intensive and uncontrolled grazing and plant collection has certainly modified the desert plant cover. Palatable plants have been nearly eliminated and may be replaced by less to unpalatable plants, which would render the area barren (Kassas \& Zahran, 1962). Kassas \& Zahran (1962) revealed that the destruction of ? [please complete the sentence]. According to Kassas \& Girgis (1965), the growth of Nitraria retusa represents the highest tolerance to soil salinity conditions. This species is common to the inland wadis of the Eastern Desert, whose vegetation entails active soil erosion that leads to the modification of the entire ecosystem. Moreover, the growth of Calligonum polygonoides is recorded only at this altitudinal range. It is a much-branched undershrub that is palatable to grazers. Communities dominated by this plant were recorded in the wadis of the Eastern Desert (Kassas \& Girgis, 1972).

\section{Desertification}

Kassas (1977) defined desertification as a reduction in the productivity of deserts. It is a result of complex interactions within coupled social-ecological systems. Furthermore, he pointed out that the high natural climate variability in dryland regions is the major cause of changes in vegetation, although it does not necessarily imply degradation.
Kassas (1976) discussed the problems and prospects of arid and semi-arid lands and conducted a survey of the world's deserts and processes of desertification. He identified issues that are strictly caused by physical factors and those that are anthropogenic. Areas of potential useful study were identified: Improved climate, climatic research and monitoring, improvement of arid zone cultivars, and improved techniques in decision-making about land use. Warnings are given of the dangers of over-intensification of agricultural systems and of increasing population density in arid zones. Research areas suitable for international cooperation are outlined. The reversal of desertification may occur naturally after the omission of contributing causes. Otherwise, human intervention may be required (Kassas, 1977).

Kassas (1995) delivered a review paper that provides an explanation and a global assessment of desertification as it continues to ravage the world's drylands. The paper illustrated the differences between drought (a natural hazard) and desertification (degradation of land resources) and quoted examples of drought management (a case study of Syria) and desertification management (a case study of drylands in the United States). It reviewed the actions of the world community led by UN in 1972-1992 in response to drought and famine that wreaked havoc on the continent of Africa. This paper included holding the UN conference on desertification in 1977 and elaborating an UN-endorsed plan of action to combat desertification and endeavors with limited success toward its implementation. Lastly, the review highlighted the world action in 1992 (UNCED) and in subsequent years (elaboration of an international convention on desertification in June 1994).

\section{Environmental education: Biodiversity}

In response to recommendations from the UNESCO and UNEP, Kassas developed and launched the International Environmental Education Program in 1977. Kassas (2002) provided a comprehensive definition of environmental education, that is, it was perceived to encompass in- and out-of-school activities and public awareness. Subsequent developments added training to the objectives and concept of sustainable development to the dimensions of the program. The international Convention on Biological Diversity represented a phase in the world commitment to the conservation of nature. 
Its biodiversity was underpinned in the fields of environmental education. Biodiversity education is based on five pivots, namely, scale of boundaries (from local to worldwide), perspectives, goals, themes (which vary according to actors), and assimilation (evaluation of programs of action). Directions related to learners and teachers and processes address awareness, school education, education (and professional training) at the tertiary level, and the roles of communication and media institutions.

\section{World conservation strategy}

Between 1978 and 1984, Mohamed Kassas became the president of the International Union for Conservation of Nature (IUCN), the world's oldest and largest environmental network, which gathers 1000 governmental and non-governmental organizations, along with 11,000 volunteers, worldwide, in 160 countries, represented the World Conservation Strategy (WCS), which provides an intellectual framework and practical guidance for the necessary conservation actions. It calls for globally coordinated efforts motivated by will and determination for concerted movements at the national and international levels. Furthermore, the strategy requires global solidarity to implement its programs. Worldwide action to produce the practical effects of this strategy is a necessary complement to a worldwide program for the rational development of the resources of the planet. Development and conservation are equally necessary for survival and for the discharge of responsibilities to trustees of natural resources for future generations.

The WCS was commissioned by the UNEP, which provided the financial support for its preparation and contributed to the evolution of its basic themes and structure, along with the World Wildlife Fund. The aim objective of the WCS was to advance the achievement of sustainable development through the conservation of living resources. The Strategy aims to (a) Elucidate the contribution of living resource conservation to human survival and sustainable development, (b) Identify priority conservation issues and the major requirements for addressing such issues, (c) Proposes effective methods for achieving these objectives. The Strategy is intended to stimulate a focused approach to the conservation of living resources and to provide policy guidance on its implementation. Furthermore, it concentrates on major problems that directly influence the achievement of the objectives of conservation and addressing them through conservation. In particular, the Strategy identifies actions required to improve conservation efficiency and the integration of conservation and development.

Therefore, the WCS defines the conservation of living resources and explains its objectives, its contribution to human survival and development, and the main impediments to its achievement. Moreover, it determines the priority requirements for achieving each objective and proposes national and subnational strategies to meet the priority requirements by establishing the framework and principles for such strategies. It further recommends anticipatory environmental policies, a crosssectoral conservation policy, and a broad system of national accounting to integrate conservation with development at the policy making level. In addition, it proposes an integrated method for evaluating land and water reimbursements, which are supplemented by environmental assessments, as a method for improving environmental planning. It also outlines a procedure for the rational allocation of land and water use and recommends the review of legislation regarding living resources. It suggests general principles for its organization within the government and, in particular, proposes various strategies for improving organizational capacities for the conservation of soil and marine living resources. Other recommendations include means of increasing the number of trained personnel and proposals for additional management-oriented research and research-oriented management. In this manner, basic information that is most urgently required is generated rapidly. The WCS also recommends increased public participation in planning and decision-making regarding the use of living resources and presents proposals for environmental education programs and campaigns to build support for conservation. Other suggestions offered are those for helping rural communities to conserve living resources as the essential basis of the development required. In addition, the Strategy recommends international action to promote, support, and (where necessary) coordinate national action. In particular, it emphasizes the need for a strong, comprehensive international law and increased 
development assistance for conservation. It considers international programs to promote the actions necessary for conserving tropical forests and drylands, to protect areas essential for the preservation of genetic resources, and to conserve globalcommons, such as the open ocean, the atmosphere, and Antarctica. Its regional strategies aim to advance the conservation of shared living resources, particularly with respect to international river basins and seas. The WCS ends by summarizing the main requirements for sustainable development and by enumerating the conservation priorities for the Third Development Decade.

\section{A distinguished Egyptian scholar}

The Late Professor Kassas sat in his office at Cairo University from $8 \mathrm{am}$ to $12 \mathrm{pm}$ and was surrounded by files that reached the ceiling. He liked to receive visitors, such as researchers and students, who enter and exit his office in a constant ballet. Retirement, as opposed to arid land and desertification, is a concept he has no intention of realizing. Perhaps, that is for the best.

Kassas died in the early hours of March 3, 2012, a Wednesday, after a short struggle with illness, at the Nile Specialized Hospital. He was 91 years old. He was admitted to the Nile Specialized Hospital after suffering from cancer, where he underwent special medical care until his death.

Afterward, more than 100 scientists, who were once his students, stressed the need to establish the Natural History Museum, which he proposed for many years, to honor his memory as one of the symbols of environmental work worldwide. This announcement was made during a celebration of the venerable scientist's first death anniversary at the Ministry of Environment's Educational Cultural Center, where the Minister of State for Environmental Affairs presented his wife with the Ministry's shield in recognition of his contribution to environmental science in Egypt and abroad. The Minister added that they decided to publish his scientific research and references on the website of the Ministry, in addition to another website, which is being established in cooperation with his son and students. Furthermore, a magazine bearing his name will be issued, and the Environmental Retribution Salon will be established at the Cairo Educational
House to discuss and guide research in this field. Unfortunately, these promises remain unfulfilled to date.

As one of his students, I was honored to have been under his mentorship, because he taught me more than one course in the third and fourth years of the bachelor's degree. Moreover, I was the only student under him in a pre-Master's course in the field of cytology and genetics at the Department of Plant and Microbiology at Cairo University. A word of truth remains that should be said about our teacher and the experiences received by those who sit with him (Kapiel, 2021).

As stated by Dr. Samir Ibrahim Ghabbour, Emeritus Professor of the Department of Natural Resources at the Institute of African Research and Studies of Cairo University, "he is a man who had neither material ambitions, nor desires for fame, nor grudges toward anyone. His ambitions were confined to serving his country and all humanity. His desires are to help those around him, take care of them, and 'open doors for people to grow out of".

Kassas is considered the architect of the concept of desertification in the Arab world and a pioneer in proposing solutions to the problem for decades. Kassas developed his environmental knowledge in a manner that truly qualified him to be an encyclopedia of environmental sciences. Individuals who visited Kassas in his recent years at his office at the Faculty of Science of Cairo University were astonished by the many qualities he possessed. One of the most important of these qualities was his flamboyant vitality despite his advanced age. He was constantly active and extremely meticulous in dealing with information related to environmental problems that are acutely raised in the Arab world, especially the problem of desertification.

Kassas consistently advised Arab and nonArab scholars to hasten at least the accurate documentation of authentic plant wealth, especially in the Arab region. He used to tell his visitors that this wealth is threatened today by the phenomenon of extreme climatic changes, especially during periods of drought, which last longer than necessary.

However, officials from global and regional organizations concerned with the environment, 
note that Kassas was prolific in production, insightful, and humble. The IUCN is one of the organizations where the late Professor left his imprint. We wish that international and Egyptian official bodies address senior officials to celebrate the centenary of Prof. Kassas in recognition of his global scientific status and to set an example for all, especially the promising new generations in the field of scientific research, regarding loyalty to the great professors and distinguished Egyptian scholars who left a clear imprint in their fields.

Acknowledgments: The authors would like to express their deepest gratitude to the Enago Editing team and Egyptian Knowledge Bank team for sharing their input in this research. Their work and valuable comments have greatly improved the manuscript.

\section{$\underline{\text { References }}$}

Kapiel, T.Y.S. (2021) Centenary of the birth of the pioneer of the environmental movement in Egypt Prof. Mohamed Abdel-Fattah Al-Kassas. (In Arabic). ARSCO, 10 July 2021.

Kassas, M. (1952) Habitats and plant communities in the Egyptian desert. I. Introduction. Journal of Ecology, 40, 342-351.

Kassas, M. (1953) Habitat and plant communities in the Egyptian Desert: II. The features of a desert community. Journal of Ecology, 41(2), 248-256.

Kassas, M. (1955) Rainfall and vegetation in arid N.E. Africa. Plant Ecology Proceedings of Montpelier Symposium, UNESCO, Paris: pp. 49-77.

Kassas, M. (1956) The mist oasis of Erkwit, Sudan. Journal of Ecology, 44, 180-194.

Kassas, M. (1957) On the ecology of the Red Sea coastal land. Journal of Ecology, 45, 187-203.

Kassas, M. (1970) Desertification versus potential for recovery in circum-saharan territories. In: "Arid Lands in Transition", Dregne, H. (Ed.), Vol. 13, pp. 123-142. American Association for Advanced Science, Washington, DC.

Kassas, M. (1976) Arid and semi-arid lands: Problems and prospects. Agro-Ecosystems, 3, 185-204.
Kassas, M. (1977) Arid and semi-arid lands: Problems and prospects. Agro-Ecosystems, 3, 186.

Kassas, M. (1995) Desertification: a general review. Journal of Arid Environments, 2, 115-128.

Kassas, M. (1996) Two elements of an agenda 21 for North Africa. In: Proceedings of Workshop on Arid Lands Biodiversity in North Africa. Batanouny, K. and Ghabbour, S. I. (Eds.). IUCN, SDC, Cairo: pp. $7-11$.

Kassas, M. (2002) Environmental Education: Biodiversity. The Environmentalist, 22, 345-351.

Kassas, M., Imam, M. (1954) Habitat and plant communities in the Egyptian desert. III. The Wadi bed ecosystem. Journal of Ecology, 42, 424-441.

Kassas, M., Imam, M. (1959) Habitat and plant communities in the Egyptian desert. IV The gravel desert. Journal of Ecology, 47, 289-310.

Kassas, M., Zahran, M.A. (1962) Studies on the ecology of the Red Sea coastal land I. The district of Gebel Ataqa and El-Galala El-Bahariya. Bulletin de la Societe de Geographie d'Egypte, 35, 129-175.

Kassas, M., Girgis, W.A. (1964) Habitat and plant communities in the Egyptian desert: V. The limestone plateau. Journal of Ecology, 52(1), $107-$ 119.

Kassas, M., Girgis, W.A. (1965) Habitat and plant communities in the Egyptian desert: VI. The units of a desert ecosystem. Journal of Ecology, 53(3), 715-728.

Kassas, M., Zahran, M. (1965) Studies on the ecology of the Red Sea coastal land II. The district from El-Galala El-Qibliya to Hurghada. Bulletin de la Societe de Geographie d'Egypte, 38, 185-193.

Kassas, M., Girgis, W.A.(1972) Studies on the ecology of the eastern desert of Egypt. I. The region between latitude $27^{\circ} 30$ and latitude $25^{\prime \prime} 30$ N. Bulletin de la Societe de Geographie d'Egypte, 42, 43-72.

UNEP (United Nations Environment Programme) (1992) "World Atlas of Desertification", N. Middleton and D.S.G. Thomas (Eds.), Edward Arnold, London. 


\section{الأستاذ الدكتور محمد عبد الفتاح القصاص: الأب المؤسس لعلم البيئة في مصر}

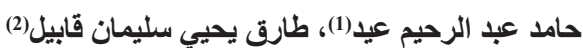

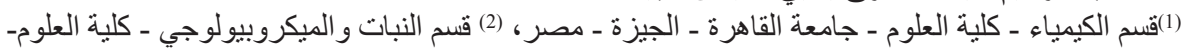
جامعة القاهرة ـ الجيزة - مصلية العلوم - مصر.

حلت الذكرى المئوية لميلاد الأستاذ الدكتور محمد عبد الفتاح القصاص (1921 - 2012) عالم البيئة النباتية يوم

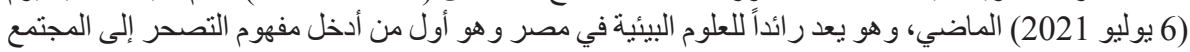

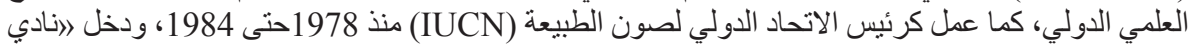

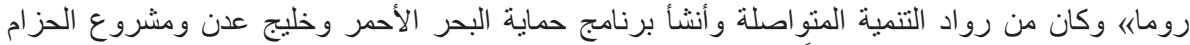

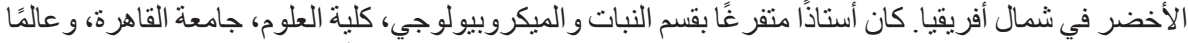

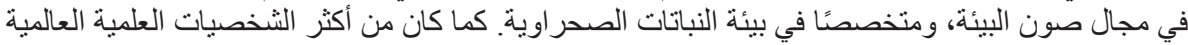

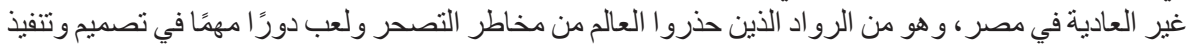

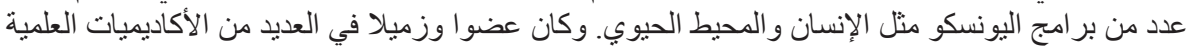

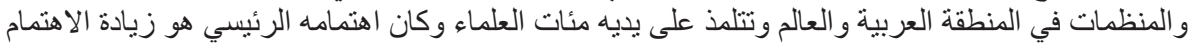

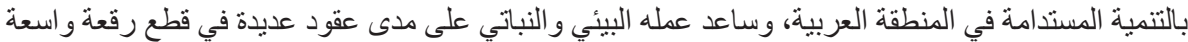

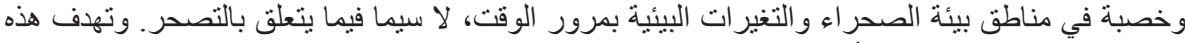
الدر اسة إلى إلقاء الضوء على على أهم إنجاز اته العلمية والبحتية. 